\title{
O B I T U A R Y
}

\section{Chancellor Michael Goodman (I930-2017)}

\author{
Mark Hill QC \\ Consultant Editor, Ecclesiastical Law Journal
}

Without Michael Goodman there would be no Ecclesiastical Law Journal. He was present at the inauguration of the Ecclesiastical Law Society in 1987 and became something of an accidental editor. Recalling those early days in the silver jubilee issue of the Journal, Michael wrote:

\begin{abstract}
Somebody said that we needed an editor for the new journal and they all looked at me. I had never edited anything before, not even the school magazine and certainly not a learned and academic tome such as those present hoped to see, but I thought it would be interesting and good fun and so agreed to take on the task. ${ }^{1}$
\end{abstract}

Michael rarely styled himself editor, preferring to be Chairman of the Editorial Committee, a body which he filled with leading scholars and practitioners. His enthusiasm and bonhomie were infectious and few turned down his invitations to contribute. He called on Ray Hemingray as production manager, who, in common with all of us who worked with Michael, constantly struggled to decipher his atrocious handwriting in scrawling blue ink.

Michael's ever-loyal wife, Pat, was regularly called up for copy-editing duty. As Michael said, 'I well remember my wife deciding to give up trying to confirm the accuracy of footnotes in Latin at about 1 am, saying that her brain could not cope any longer!' ${ }^{2}$ There was something wonderfully amateurish about those early days, where hard work, goodwill and enthusiasm substituted for knowledge and experience. With two issues per year, Michael wisely designated them 'winter' and 'summer' as one could never be entirely certain in which month they would appear. But he presided in the editor's chair until his retirement in 2002 and secured its reputation for scholarship and topicality.

$1 \quad$ M Goodman, 'The early years of the Ecclesiastical Law Journal', (2012) 14 Ecc LJ 87-92 at 88.

$2 \quad$ Ibid, p 91. 
Michael was called to the Bar in Middle Temple in 1953 and quickly developed a flourishing practice with a growing specialism in ecclesiastical law. Among his many pupils was a young Jack Straw, later to hold several of the great offices of state, including Lord Chancellor. In addition to serving 15 years as a Circuit Judge, Michael held chancellorships in glorious plurality: Guildford (1968-2002), Lincoln (1970-1998) and Rochester (1971-2005). He was Vicar General of the Province of Canterbury from 1977 to 1983 and Chairman of the Ecclesiastical Judges Association from 1987 to 1997. As the Society's President, Sheila Cameron QC DCL, reminded those privileged to be at Michael's funeral in his beloved church of St Stephen's Dulwich, Michael delighted at being invited by Sir John Owen to join the first panel of three judges sitting en bloc to determine an appeal to the Court of Arches. ${ }^{3}$ Hitherto the dean had sat alone, but the change was welcomed by Michael and other as strengthening the ecclesiastical common law, and creating a stronger esprit de corps among its judiciary. In due course one of Michael's more newsworthy judgments, concerning a claimed illegitimate descendant of a daughter of Queen Victoria, was later pored over by a bench of the Court of Arches - and upheld. ${ }^{4}$

Michael helped establish the ecclesiastical law collection within Middle Temple library, which now constitutes one of the most prestigious holdings of Anglican canon law in the world. And he was particularly industrious, ably assisted by the meticulous Peter Moore, in collating judgments of the ecclesiastical courts. Indexed and beautifully bound in imperial purple, these Consistory and Commissary Court Cases (or CCCC, as they came to be known) provided a repository of the ecclesiastical common law which was otherwise not available. In a bygone age, long before obligatory neutral citation was prescribed by the Dean of Arches, accessing judicial precedent had been more miss than hit. Michael's initiative revolutionised this, and it is a source of sadness that he did not live to see volunteers make good their promise to put all this material on the internet.

For many years Michael chaired the patronage trust for St Cuthbert, Philbeach Gardens, but never exercised his right of presentation, in consequence of the longevity in office of its nonagenarian incumbent, Fr Vine, who held the freehold from 1969 to 2013 . For a quarter of a century he brought wit and wisdom to the Legal Advisory Commission of the General Synod.

Michael had an expansive hinterland and his rich life included involvement in activities in Dulwich and beyond. He regularly performed with a variety of choral societies, and was a demon on the croquet lawn. In everything he did, he enjoyed the unstinting support of his wife, Pat. They were devoted to their 
daughters, Sarah and Catherine, and to their grandchildren, and immeasurably proud of all their achievements.

A plain stone plaque in the crypt of St Paul's Cathedral bears an inscription to its architect, Sir Christopher Wren: Reader, if you seek his monument - look around you. Michael will be remembered with affection by his family and his many friends. But his lasting memorial will be this Journal, which he established, nurtured and made to flourish. The Society will be forever in the debt of Michael Goodman, Founder Editor of the Ecclesiastical Law Journal. 